\title{
[Review Paper]
}

\section{Selective Conversion of Fuel-bound Nitrogen to $\mathrm{N}_{2}$ with Iron Nanoparticles}

\author{
Yasuo OHTSUKA \\ Research Center for Organic Resources and Materials Chemistry, Institute for Chemical Reaction Science, \\ Tohoku University, Katahira, Aoba-ku, Sendai 980-8577
}

(Received July 3, 1997)

\begin{abstract}
The highlight of this review article is a novel method to remove fuel-bound nitrogen as $\mathrm{N}_{2}$ during coal pyrolysis in an inert atmosphere.

When a $\mathrm{Cl}$-free iron catalyst is precipitated on Australian brown coal from $\mathrm{FeCl}_{3}$ solution using $\mathrm{Ca}(\mathrm{OH})_{2}, \mathrm{~N}_{2}$ yield increases with increasing pyrolysis temperature and reaches $50 \%$ at $900^{\circ} \mathrm{C}$, whereas it is $<5 \%$ without the iron. A low loading ( $1 \mathrm{wt} \% \mathrm{Fe}$ ) is sufficient for the remarkable formation of $\mathrm{N}_{2}$, and the use of $\mathrm{H}_{2}$ instead of inert $\mathrm{He}$ is unnecessary. The iron catalyst decreases the partitioning to not only volatile nitrogen (tar, $\mathrm{HCN}$, and $\mathrm{NH}_{3}$ ) but also char nitrogen. A smaller catalytic effect of the precipitated iron is observed with bituminous coal. The iron catalyst after pyrolysis exists as fine particles with a smaller size of $20-30 \mathrm{~nm}$ for the brown coal char, $\mathrm{Fe}_{3} \mathrm{C}$ and graphitized carbon being also present. It is likely that $\mathrm{N}_{2}$ originates mainly from solid phase reactions involving the formation and subsequent decomposition of iron nitrides.

In the pyrolysis of different coals at $1000^{\circ} \mathrm{C}, \mathrm{N}_{2}$ yields for low-rank coals from China and Germany reach 50 $60 \%$ despite the absence of catalyst. Demineralization with $\mathrm{HCl}$ washing removes mainly $\mathrm{Fe}$ and $\mathrm{Ca}$ elements from these coals and drastically decreases $\mathrm{N}_{2}$ yield with a corresponding increase in nitrogen retention in the chars. The $\mathrm{Ca}$ ion-exchanged with the demineralized coals is inactive for $\mathrm{N}_{2}$ formation. Iron nanoparticles, derived from Fe-containing minerals, catalyze predominantly solid phase reactions to extract $\mathrm{N}_{2}$ from char and/or precursors.
\end{abstract}

\section{Introduction}

The nitrogen present in fossil fuels, such as coal and heavy oil, that is, fuel-bound nitrogen (fuel-N), exists mostly as heteroatoms within aromatic rings, and is the source of nitrogen oxide pollutants emitted during combustion. The nitrogen content of coal on a dry, ashfree basis mainly ranges from 0.5 to $2 \mathrm{wt} \%$, which is several orders of magnitude greater than that of heavy oil. Technologies for the control of emissions of nitrogen oxide pollutants are thus more important in coal combustion processes.

When coal is burnt, $\mathrm{NO}_{x}$ and $\mathrm{N}_{2} \mathrm{O}$ are emitted. In conventional pulverized coal-fired plants, $75-95 \%$ of the $\mathrm{NO}_{x}$ consist of fuel-NO , which originates from fuel-N, the remainder being thermal $\mathrm{NO}_{x}$ from air ${ }^{1)-3)}$. As is well-known, $\mathrm{NO}_{x}$ has been implicated in acid rain and photochemical smog formation. Various technologies, such as combustion modifications and flue gas treatment, have thus been developed to comply with regulations concerning $\mathrm{NO}_{x}$ emissions from coal combustion $^{1)-3)}$.

On the other hand, $\mathrm{N}_{2} \mathrm{O}$ emissions from conventional combustion are low ${ }^{4,5)}$. It has been suggested, however, that some $\mathrm{NO}_{x}$ abatement and control technologies increase the $\mathrm{N}_{2} \mathrm{O}$ emissions. Further, fluidized bed combustion of coal, which has improved environmental performance and can be operated at a lower tempera- ture than in pulverized coal-fired boilers, emits considerably higher concentration of $\mathrm{N}_{2} \mathrm{O}^{4), 5}$. $\quad \mathrm{N}_{2} \mathrm{O}$ is known to be involved in both the greenhouse effect and the ozone layer depletion, but it appears that any technologies for the control of $\mathrm{N}_{2} \mathrm{O}$ have not yet been developed.

When coal is fed into a combustion chamber, the pyrolysis (devolatilization) first takes place, and subsequently volatiles released from coal and remaining solid residues (called "char") react with $\mathrm{O}_{2}$. A simplified scheme of $\mathrm{NO}_{x}$ and $\mathrm{N}_{2} \mathrm{O}$ emissions from coal is thus illustrated in Fig. 1, where coal-N, tar-N, and char- $\mathrm{N}$ mean the nitrogen present in coal, tar, and char, respectively, and volatile- $\mathrm{N}$ comprises tar- $\mathrm{N}, \mathrm{HCN}$, and $\mathrm{NH}_{3}$. Upon pyrolysis, part of coal-N is initially released as tar- $\mathrm{N}$ and the remainder is retained as char-

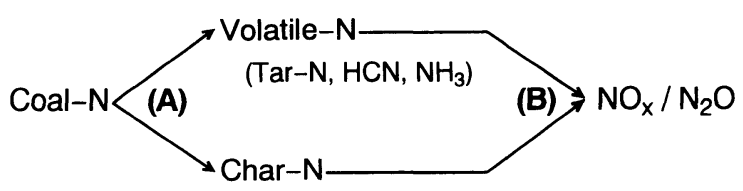

(A); Pyrolysis step

(B); Combustion step

Fig. 1 A Simplified Scheme of $\mathrm{NO}_{x}$ and $\mathrm{N}_{2} \mathrm{O}$ Emissions in a Coal Combustion Process 
Table 1 Ultimate and Proximate Analyses of Coals Used

\begin{tabular}{|c|c|c|c|c|c|c|c|c|}
\hline \multirow{2}{*}{ Coal (code) } & \multicolumn{5}{|c|}{ Ultimate analysis [wt\% (daf)] } & \multicolumn{3}{|c|}{ Proximate analysis $[\mathrm{wt} \%(\mathrm{db})]$} \\
\hline & $\mathrm{C}$ & $\mathrm{H}$ & $\mathrm{N}$ & $S$ & $\mathrm{O}^{\mathrm{a})}$ & Ash & $\mathrm{VM}^{\mathrm{b})}$ & $\mathrm{FC}^{\mathrm{c})}$ \\
\hline Rhein Braun (RB) & 64.4 & 4.8 & 0.74 & 0.3 & 29.8 & 4.7 & 54.4 & 40.9 \\
\hline Loy Yang (LY) & 65.9 & 4.7 & 0.60 & 0.3 & 28.5 & 0.5 & 51.0 & 48.5 \\
\hline Zalainuoer (ZN) & 72.0 & 5.0 & 1.7 & 0.4 & 21.0 & 4.1 & 42.5 & 53.4 \\
\hline Blair Athol (BA) & 78.6 & 4.4 & 2.0 & 0.3 & 14.7 & 7.5 & 28.7 & 63.8 \\
\hline
\end{tabular}

a) Determined by difference. b) Volatile matter. c) Fixed carbon.

$\mathrm{N}$, tar- $\mathrm{N}$ being subsequently decomposed into $\mathrm{HCN}$ and $\left.\mathrm{NH}_{3}{ }^{6)}-8\right)$.

If coal- $\mathrm{N}$ can be converted efficiently to $\mathrm{N}_{2}$ in the pyrolysis stage, the $\mathrm{NO}_{x}$ and $\mathrm{N}_{2} \mathrm{O}$ emissions can be greatly reduced during subsequent combustion. This conversion must be more effective in fluidized bed combustion, since the $\mathrm{NO}_{x}$ and $\mathrm{N}_{2} \mathrm{O}$ emitted in this process arise from coal-N alone. Such a precombustion method of nitrogen removal would be one of the most essential ways to meet more stringent regulations in the near future. No successful approaches, however, have yet been reported. This review article describes a novel method to convert coal- $\mathrm{N}$ to $\mathrm{N}_{2}$ with iron nano-particles.

\section{Experimental}

\section{1. Coal and Polymer Samples}

Many coals with different ranks were used. Among them, Rhein Braun coal from Germany, Loy Yang coal from Australia, Zalainuoer coal from China, and Blair Athol coal from Australia were mainly used, and these are denoted as $\mathrm{RB}, \mathrm{LY}, \mathrm{ZN}$, and $\mathrm{BA}$ throughout the present paper, respectively. All of the samples were dried in a laboratory air, ground, and sieved to obtain coal particles in the range of $150-250 \mu \mathrm{m}$. The proximate and ultimate analyses of the four coals are shown in Table 1.

Polyacrylonitrile (PAN) with the average molecular weight of 150,000 , from Polysciences Inc., was also used instead of coal samples, since PAN has a much higher nitrogen content of $26.4 \mathrm{wt} \%$ and provides $\mathrm{N}$ containing heterocyclic ring structures similar to coal-N upon pyrolysis.

\section{2. Addition of Catalyst}

Since $\mathrm{FeCl}_{3}$ is readily available as a major component in acid wastes from a steel pickling plant, an aqueous solution of $\mathrm{FeCl}_{3}$ was used as a catalyst precursor. A Cl-free iron catalyst in highly dispersed forms was precipitated on coal from $\mathrm{FeCl}_{3}$ solution by using $\mathrm{Ca}(\mathrm{OH})_{2}{ }^{9), 10}$. The procedure has been described in detail elsewhere ${ }^{10)}$ and thus it is simply explained below. After a predetermined amount of $\mathrm{Ca}(\mathrm{OH})_{2}$ powder with a constant molar ratio of $\mathrm{Ca}(\mathrm{OH})_{2} / \mathrm{FeCl}_{3}$ was first added to a mixture of coal particles and $\mathrm{FeCl}_{3}$ solution, the resulting iron-bearing coal was separated by filtration, then washed repeatedly with deionized water, and finally dried at $110^{\circ} \mathrm{C}$ in a flow of $\mathrm{N}_{2}$.

$\mathrm{Cl}$ determination of the dried sample by a standard Eschka method revealed that the iron precipitated on coal was free from $\mathrm{Cl}$ contamination ${ }^{10)}$. The $\mathrm{Cl}$ ions in $\mathrm{FeCl}_{3}$ solution could be removed completely as watersoluble $\mathrm{CaCl}_{2}$. Excess $\mathrm{Ca}(\mathrm{OH})_{2}$ on the iron-bearing coal was also removed almost completely by repeated water-washing after filtration, but a slight amount of $\mathrm{Ca}, \leq 0.5 \mathrm{wt} \%$, was retained.

In another method for addition of catalyst, a nanophase iron oxide catalyst with an average particle size of $3 \mathrm{~nm}$, from Mach I, Inc. ${ }^{11)}$, was added to BA coal by mixing in ethanol at ambient temperature. When PAN was used instead of coal, fine particles of $\mathrm{Fe}$ metal with a mean particle size of $20 \mathrm{~nm}$, from Vacuum Metallurgical Co., were also added by soaking with PAN in acetone under ultrasonic wave irradiation $^{12)}$.

\section{3. Pyrolysis Runs}

Pyrolysis runs of coal samples were carried out with a quartz-made fluidized or fixed bed reactor. The former reactor with the bed zone of $2.5 \mathrm{~cm}$ i.d. and $35 \mathrm{~cm}$ long was heated with a transparent, electric furnace, which made it possible to watch the fluidization state of coal particles. About $5 \mathrm{~g}$ of the iron-bearing coal was first fluidized in atmospheric $\mathrm{He}$, then heated at 600 $700 \mathrm{~K} / \mathrm{min}$ up to $750-1000^{\circ} \mathrm{C}$, and finally soaked for 10 min. Any fluidizing agents such as sand were not used to avoid their possible influence on nitrogen release upon pyrolysis. The procedure has been described in more detail elsewhere ${ }^{13), 14)}$.

With the fixed bed pyrolysis, a rectangular graphite cell (6 mm wide, $46 \mathrm{~mm}$ long, $8 \mathrm{~mm}$ deep) including about $0.5 \mathrm{~g}$ of coal particles was placed in the center of the reactor ( $4 \mathrm{~cm}$ i.d., $37 \mathrm{~cm}$ long), which was heated at $400 \mathrm{~K} / \mathrm{min}$ in a stream of high-purity $\mathrm{He}(>99.9999 \%)$ with an electric furnace with infrared image lamps attached and soaked for $2 \mathrm{~min}$ at a constant temperature. Special care was taken to ensure that the entire system was free from any leakage before every run. The details of the reactor and procedure have been described in the previous papers ${ }^{15), 16)}$.

The pyrolysis of PAN with and without fine metal 
particles was carried out with a thermobalance, and 40 $\mathrm{mg}$ of the sample was heated at $10 \mathrm{~K} / \mathrm{min}$ in a flow of high-purity $\mathrm{He}$ at atmospheric pressure.

\section{4. Analysis of Nitrogen}

Pyrolysis products from coal samples were separated into gas, tar (including oil fraction), and $\operatorname{char}^{14,16)}$. The concentration of $\mathrm{N}_{2}$ in the gas collected in a plastic bag was analyzed by gas chromatography with a thermal conductivity detector. The amount of $\mathrm{N}_{2}$ evolved was determined by the difference in $\mathrm{N}_{2}$ concentration before and after pyrolysis. $\mathrm{HCN}$ and $\mathrm{NH}_{3}$ were analyzed by two different methods. One included dissolution of $\mathrm{HCN}$ and $\mathrm{NH}_{3}$ evolved into deionized water and subsequent determination of dissolved $\mathrm{CN}^{-}$and $\mathrm{NH}_{4}{ }^{+}$ions with a specific ion electrode ${ }^{14}$. In another method, the concentration of $\mathrm{HCN}$ or $\mathrm{NH}_{3}$ in the gas collected was analyzed by the Gastec standard detector tube ${ }^{16)}$. To ensure the accuracy of this method, these gases were also analyzed by a Fourier transform infrared spectrometer equipped with a long path gas cell, and it was confirmed that the concentrations determined by both methods fell within experimental errors.

The nitrogen in the tar or char recovered, denoted as tar- $\mathrm{N}$ or char- $\mathrm{N}$ respectively, was determined with a conventional, combustion-type elemental analyzer.

The amount of $\mathrm{N}_{2}$ evolved from PAN samples was analyzed by on-line gas chromatography, and the nitrogen in the carbon after pyrolysis was determined in the same manner as above.

\section{5. Characterization}

Mössbauer spectra were measured at room temperature with a constant acceleration spectrometer ${ }^{17)}$, and isomer shift (IS) and quadrupole splitting (QS) were used as Mössbauer parameters. X-Ray diffraction (XRD) measurements were made with $\mathrm{Mn}$-filtered $\mathrm{Fe}$ $\mathrm{K} \alpha$ radiation. Some samples were also characterized by the $\mathrm{Fe} 2 \mathrm{p} 3 / 2$ or $\mathrm{N} 1 \mathrm{~s} X$-ray photoelectron spectroscopy (XPS) using $\mathrm{Mg} \mathrm{K} \alpha$ radiation. The specimen was ground and mounted on a sample holder using Ag paste. A long acquisition time of several hours was used to ensure good resolution, and the binding energy was referred to the $\mathrm{Ag} 3 \mathrm{~d}$ peak at $367.9 \mathrm{eV}$. The dispersion and chemical composition of iron catalysts and inherent minerals in the chars after pyrolysis at $900-1000^{\circ} \mathrm{C}$ were also analyzed with a high resolution transmission electron microscopy (TEM) with an energy-dispersive X-ray analyzer (EDX) attached.

\section{Results and Discussion}

\section{1. Formation of $\mathbf{N}_{2}$ from PAN}

Rate of formation of $\mathrm{N}_{2}$ as a function of temperature is illustrated in Fig. 2, where the rate is expressed on the basis of the initial weight of PAN, and $\mathrm{Fe}(\mathrm{prec})$ and $\mathrm{Fe}$ (fine) mean precipitated iron and fine iron particles, respectively. In the absence of the iron, $\mathrm{N}_{2}$ started to

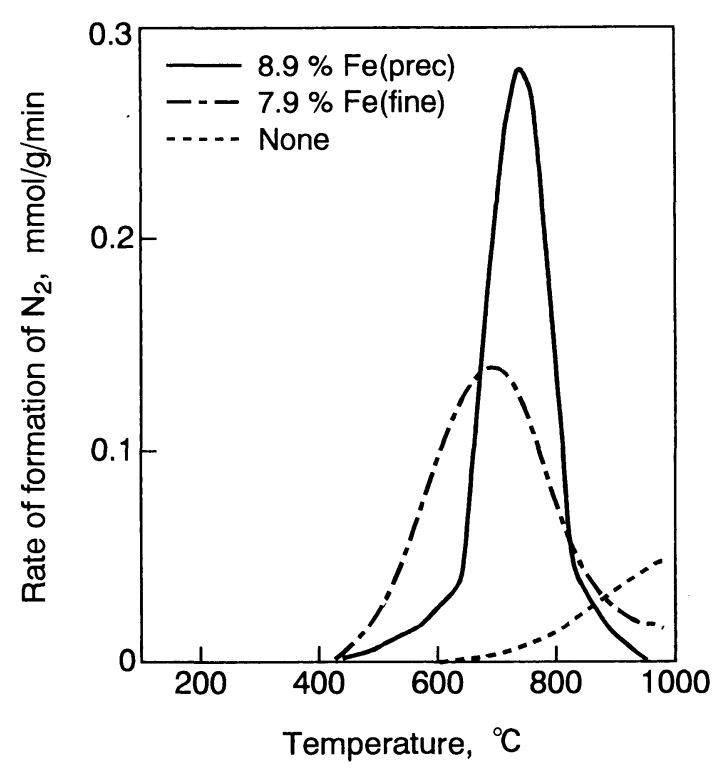

Fig. 2 Rate of Formation of $\mathrm{N}_{2}$ during Temperature Programmed Pyrolysis of Polyacrylonitrile

evolve significantly beyond $700^{\circ} \mathrm{C}$ as reported in several studies ${ }^{18,19)}$, and the rate around $1000^{\circ} \mathrm{C}$ was as low as $<0.05 \mathrm{mmol} / \mathrm{g}-\mathrm{PAN} / \mathrm{min}^{12)}$. On the other hand, the addition of fine iron at a loading of $7.9 \mathrm{wt} \%$ not only lowered the onset temperature of $\mathrm{N}_{2}$ formation by $\approx 200^{\circ} \mathrm{C}$ but also increased the rate between $600^{\circ} \mathrm{C}$ and $900^{\circ} \mathrm{C}$ remarkably. When the iron was precipitated onto PAN from $\mathrm{FeCl}_{3}$ solution, the rate increased further in the temperature region of $700-800^{\circ} \mathrm{C}$, which lead to a two-fold increase in the maximum rate, compared with that for fine iron ${ }^{20)}$.

Table 2 shows the effect of iron addition on $\mathrm{N}_{2}$ yield which is defined as conversion of the nitrogen present in PAN (denoted as PAN-N) to $\mathrm{N}_{2}$. The yield was $\approx 5 \%$ for PAN alone and almost unchanged by the addition of coarse particles of iron metal. On the other hand, the presence of fine particles and precipitated iron increased $\mathrm{N}_{2}$ yield drastically as can be expected from Fig. 2, and the yield for the latter iron reached $42 \%{ }^{20)}$. The precipitated iron was thus more active for conversion reactions of PAN-N to $\mathrm{N}_{2}$.

Elemental analysis of carbons formed by pyrolysis is also summarized in Table 2. The nitrogen content was as large as $12 \mathrm{wt} \%$ for PAN alone, whereas it decreased to $4.3 \mathrm{wt} \%$ or $3.5 \mathrm{wt} \%$ for fine or precipitated iron, respectively. It is evident that a higher yield of $\mathrm{N}_{2}$ results in lower nitrogen retention in the carbon. Table 2 also indicates that the carbon with a lower $\mathrm{N} / \mathrm{C}$ ratio is more aromatized. This agrees with the XRD results that crystallized carbon is observed only in the presence of these iron.

When PAN is pyrolyzed and then carbonized, cyclization and dehydrogenation reactions first take 
Table $2 \mathrm{~N}_{2}$ Yield during Temperature Programmed Pyrolysis of Polyacrylonitrile up to $1000^{\circ} \mathrm{C}$ and Elemental Analysis of Carbons Formed

\begin{tabular}{|c|c|c|c|c|c|c|c|c|}
\hline \multicolumn{2}{|c|}{ Addition of iron } & \multirow[b]{2}{*}{$\begin{array}{l}\mathrm{N}_{2} \text { yield } \\
{[\mathrm{N}-\%]}\end{array}$} & \multicolumn{4}{|c|}{ Content $[w t \%$ (daf)] } & \multicolumn{2}{|c|}{ Atomic ratio } \\
\hline Type of iron & $\begin{array}{l}\text { Loadinga) } \\
\text { [wt } \%]\end{array}$ & & $\mathrm{C}$ & $\mathrm{H}$ & $\mathrm{N}$ & $\mathrm{O}^{\mathrm{b})}$ & $\mathrm{H} / \mathrm{C}$ & $\mathrm{N} / \mathrm{C}$ \\
\hline - & 0 & 4.7 & 79.1 & 0.3 & 12.1 & 8.5 & 0.05 & 0.13 \\
\hline Metal powder' & 6.6 & 5.1 & - & - & - & - & - & - \\
\hline Fine particles ${ }^{d)}$ & 7.9 & 33 & 93.6 & 0.3 & 4.3 & 1.8 & 0.04 & 0.039 \\
\hline Precipitated iron & 8.9 & 42 & 95.2 & 0.2 & 3.5 & 0.2 & 0.02 & 0.031 \\
\hline
\end{tabular}

a) Determined from ash content after burning. b) Determined by difference. c) Size fraction 44-74 $\mu \mathrm{m}$. d) Average particle size of $20 \mathrm{~nm}$.

place, which leads to the formation of the ladder polymers including heterocyclic nitrogen, and they subsequently undergo condensation and aromatization reactions to form carbon with graphite-like structures ${ }^{18), 19)}$.

In these processes $\mathrm{NH}_{3}, \mathrm{HCN}$, and $\mathrm{N}_{2}$ are evolved from PAN, and the former two are released at lower temperatures than $\mathrm{N}_{2}$. The $\mathrm{N}_{2}$ observed at $\leq 600^{\circ} \mathrm{C}$ in the presence of fine or precipitated iron would thus be formed by secondary decomposition reactions of $\mathrm{NH}_{3}$ and $\mathrm{HCN}$ with these iron. It has been accepted that $\mathrm{N}_{2}$ formation from PAN alone proceeds at $\geq 700^{\circ} \mathrm{C}$ through condensation reactions of the ladder polymers ${ }^{18), 19)}$. The remarkable enhancement of the formation rate by iron catalysts observed in this work, therefore, points out that the iron markedly promotes solidphase reactions to extract $\mathrm{N}_{2}$ from the polymers, which results in the formation of a more aromatized carbon with a lower nitrogen content (Table 2).

Since fuel-N has almost the same heterocyclic ring structures as those derived from PAN, it is expected from the above-mentioned observations that the iron precipitated onto coal from $\mathrm{FeCl}_{3}$ solution can also catalyze more effectively conversion of fuel- $\mathrm{N}$ to $\mathrm{N}_{2}$ upon pyrolysis than the physically mixed fine particles of iron metal. The following section thus focuses on $\mathrm{N}_{2}$ formation during pyrolysis of coals with precipitated iron.

\section{2. Nitrogen Release during Pyrolysis of Coals with Precipitated Iron}

\section{2. 1. Catalytic Effect on Distribution of $\mathrm{HCN}$, $\mathrm{NH}_{3}$, and $\mathrm{N}_{2}$}

Table 3 shows the distribution of gas phase $\mathrm{N}$ during pyrolysis of $\mathrm{LY}$ coal at $900^{\circ} \mathrm{C}^{14)}$. Without the catalyst, $\mathrm{NH}_{3}$ was the predominant product followed by $\mathrm{HCN}$, whereas $\mathrm{N}_{2}$ was the minor species. It has been suggested that $\mathrm{NH}_{3}$ originates from secondary reactions of $\mathrm{HCN}^{21)-23)}$ and that a larger extent of secondary reactions between volatiles and char results in higher conversion to $\mathrm{NH}_{3}{ }^{8}$. The dominant formation of $\mathrm{NH}_{3}$ shown in Table 3 thus suggests the significance of the secondary decomposition of volatile- $\mathrm{N}$ under the present conditions.

As shown in Table 3, the addition of a small amount of the iron, $0.7 \mathrm{wt} \%$, to LY coal changed the distribu-
Table 3 Distribution of $\mathrm{HCN}, \mathrm{NH}_{3}$, and $\mathrm{N}_{2}$ Evolved during Pyrolysis of LY Coal at $900^{\circ} \mathrm{C}$

\begin{tabular}{|c|c|c|c|c|}
\hline \multirow{2}{*}{$\begin{array}{c}\text { Iron loading } \\
\text { [wt\%] }\end{array}$} & \multicolumn{4}{|c|}{ Amount evolved $[\mu \mathrm{mol} / \mathrm{g}$-coal (daf)] } \\
\hline & $\mathrm{HCN}$ & $\mathrm{NH}_{3}$ & $\mathrm{~N}_{2}$ & Total \\
\hline 0 & $28(25)^{a}$ & $76(67)^{a)}$ & $9.0(8)^{\mathrm{a})}$ & 113 \\
\hline 0.73 & 10 (6) & $50(28)$ & $118 \quad(66)$ & 178 \\
\hline 2.8 & $6.1(3)$ & $62(32)$ & $(65)$ & 193 \\
\hline
\end{tabular}

a) Proportion in $\mathrm{mol} \%$.

tion of $\mathrm{HCN}, \mathrm{NH}_{3}$, and $\mathrm{N}_{2}$ drastically; $\mathrm{N}_{2}$ was the dominant product, and the amount was 13 times that without the catalyst, the proportion of $\mathrm{N}_{2}$ reaching 66 mol\%. In contrast, the presence of the iron decreased the amounts of $\mathrm{HCN}$ and $\mathrm{NH}_{3}$. The remarkable increase in $\mathrm{N}_{2}$ by catalyst addition led to the increased total amount of $\mathrm{HCN}, \mathrm{NH}_{3}$, and $\mathrm{N}_{2}$. When iron loading was increased further to $2.8 \mathrm{wt} \%$, the nitrogen distribution did not change significantly.

\section{2. 2. Factors Influencing $\mathrm{N}_{2}$ Formation}

Figure 3 shows the effect of pyrolysis temperature on formation of $\mathrm{N}_{2}$ from LY coal ${ }^{24)}$. Without the iron, $\mathrm{N}_{2}$ yield at a heating rate of $700 \mathrm{~K} / \mathrm{min}$ increased slightly with increasing temperature, but it was $<5 \%$ even at $900^{\circ} \mathrm{C}$. In contrast, the yield in the presence of the catalyst increased remarkably with temperature, and it reached $15 \%$ and $50 \%$ at $750^{\circ} \mathrm{C}$ and $900^{\circ} \mathrm{C}$, respectively. When heating rate was decreased to $30 \mathrm{~K} / \mathrm{min}, \mathrm{N}_{2}$ yield at $900^{\circ} \mathrm{C}$ increased slightly. Thus, formation of $\mathrm{N}_{2}$ from LY coal with precipitated iron depended strongly on temperature.

Figure 4 summarizes the effects of iron loading, coexistence of $\mathrm{Ca}$, fluidizing gas, and coal type on $\mathrm{N}_{2}$ formation at $900^{\circ} \mathrm{C}^{13), 14), 24)}$. In the pyrolysis of LY coal in $\mathrm{He}$, the iron at a low loading of $0.7 \mathrm{wt} \%$ promoted $\mathrm{N}_{2}$ formation dramatically, and $\mathrm{N}_{2}$ yield reached $50 \%$. However, it seemed to level off beyond $\approx 1 \mathrm{wt} \% \mathrm{Fe}$. The catalytic effect at lower loadings of $<0.7 \mathrm{wt} \% \mathrm{Fe}$ should be the subject of future work. When $\mathrm{Ca}(\mathrm{OH})_{2}$ was co-loaded onto LY coal, $\mathrm{N}_{2}$ yield at $4.5 \mathrm{wt} \% \mathrm{Fe}$ was almost unchanged. In other words, the $\mathrm{Ca}$ did not affect the catalysis of $\mathrm{N}_{2}$ formation by the iron. This observation is interesting from a view-point of in situ 


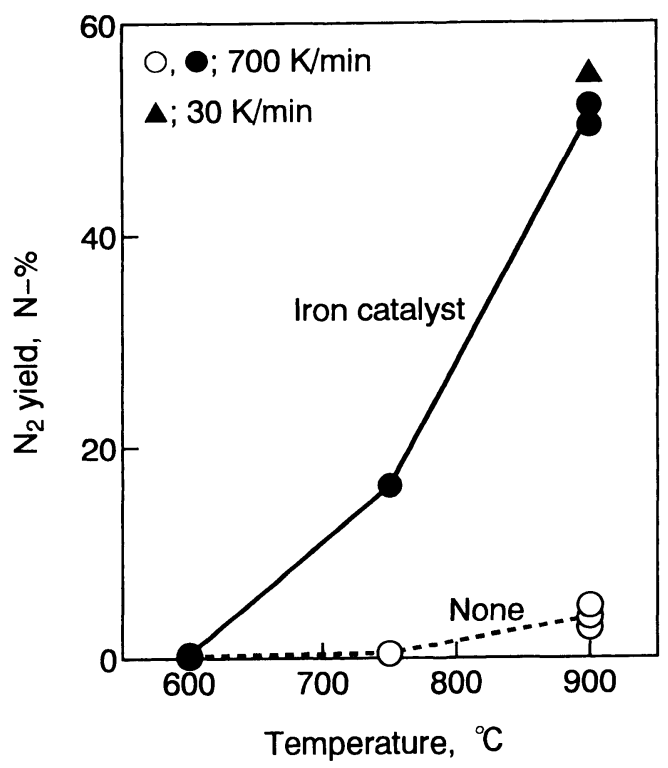

Fig. 3 Effects of Iron Catalyst and Pyrolysis Temperature on $\mathrm{N}_{2}$ Yield during Pyrolysis of Loy Yang Coal

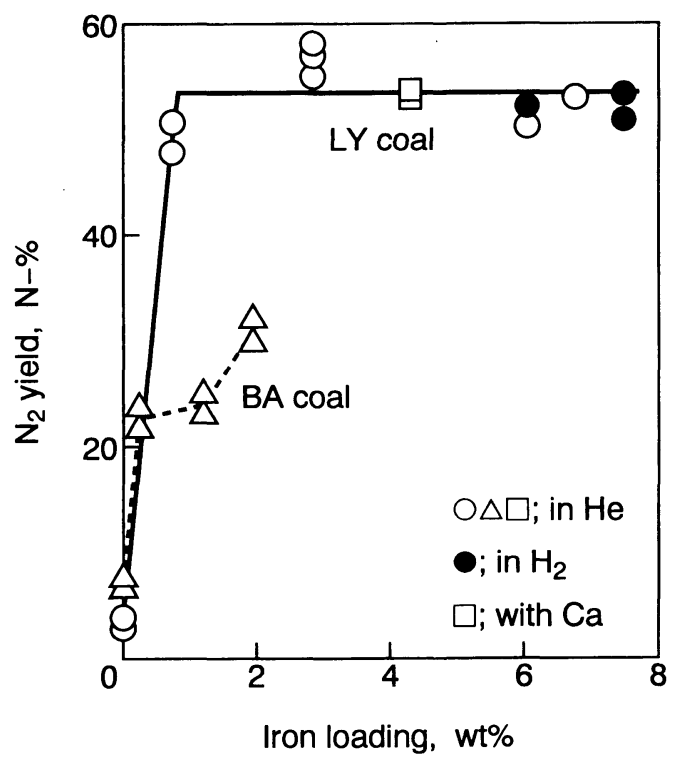

Fig. 4 Effects of Iron Loading, Pyrolysis Conditions, and Type of Coal on $\mathrm{N}_{2}$ Yield at $900^{\circ} \mathrm{C}$

desulfurization during coal pyrolysis, since the $\mathrm{CaO}$ derived from $\mathrm{Ca}(\mathrm{OH})_{2}$ added to coal can efficiently capture the sulfur evolved ${ }^{25}$.

Figure 4 also reveals that the use of $\mathrm{H}_{2}$ instead of $\mathrm{He}$ as a fluidizing gas shows no further improvement on $\mathrm{N}_{2}$ yields at loadings of 6-8 wt $\% \mathrm{Fe}$. This is noteworthy from a practical point of view, since expensive $\mathrm{H}_{2}$ is unnecessary for the iron-catalyzed removal of nitrogen from coal. In contrast to the present finding, it is well known that pressurized $\mathrm{H}_{2}$ is essentially needed for hydrodenitrogenation reactions of heavy oils and

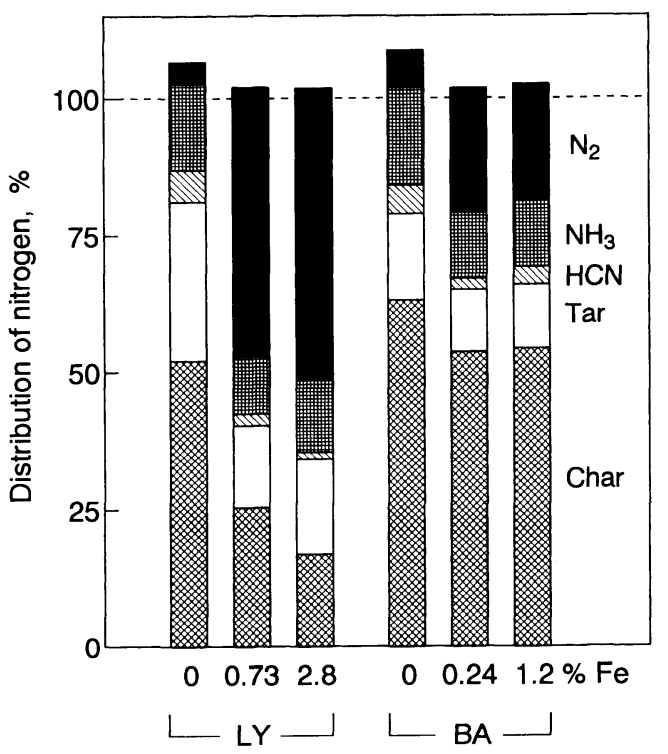

Fig. 5 Fate of Fuel Nitrogen during Pyrolysis of Loy Yang and Blair Athol Coals at $900^{\circ} \mathrm{C}$

coal-derived liquids with Mo-based catalysts.

As shown in Fig. 4, the catalytic effect of the precipitated iron on $\mathrm{N}_{2}$ formation depended on type of coal. A slight amount of the catalyst, $0.2 \mathrm{wt} \% \mathrm{Fe}$, promoted formation of $\mathrm{N}_{2}$ from BA coal, but further improvement on $\mathrm{N}_{2}$ yield was very small, even when iron loading exceeded $0.5 \mathrm{wt} \%$. The smaller catalytic effect observed for BA coal can be ascribed to lower dispersion of the iron, as will be discussed later.

\section{2. 3. Fate of Fuel Nitrogen}

Fate of fuel nitrogen in LY or BA coal during pyrolysis at $900^{\circ} \mathrm{C}$ is illustrated in Fig. 5, where each yield of $\mathrm{N}_{2}, \mathrm{NH}_{3}, \mathrm{HCN}$, tar- $\mathrm{N}$, or char- $\mathrm{N}$ is provided ${ }^{14)}$. Nitrogen mass balance fell within the reasonable range $100-108 \%$ in every case. For LY coal without the iron, about $50 \%$ of fuel- $\mathrm{N}$ was retained in the char, while tar- $\mathrm{N}$ and $\mathrm{NH}_{3}$ were the main products. When $0.7 \mathrm{wt} \% \mathrm{Fe}$ was added, the nitrogen distribution changed dramatically. $\mathrm{N}_{2}$ was the dominant product, whereas the partitioning to all other nitrogen such as $\mathrm{NH}_{3}, \mathrm{HCN}$, tar- $\mathrm{N}$, and char- $\mathrm{N}$ decreased. The catalyst at $2.8 \mathrm{wt} \%$ showed almost the same trend, though $\mathrm{N}_{2}$ yield increased slightly with a corresponding decrease in char- $\mathrm{N}$ yield.

When BA coal was pyrolyzed in the absence of the iron, as shown in Fig. 5, a similar distribution to that for LY coal without the catalyst was observed; about $65 \%$ of fuel- $\mathrm{N}$ was retained as char- $\mathrm{N}$, and tar- $\mathrm{N}$ and $\mathrm{NH}_{3}$ were mainly released. Small amounts $(0.2-1 \mathrm{wt} \%)$ of the iron precipitated onto $\mathrm{BA}$ coal increased $\mathrm{N}_{2}$ yield, whereas it decreased all other nitrogen components. This trend was the same as with LY coal. There were, however, the major differences in yields of 
$\mathrm{N}_{2}$ and char- $\mathrm{N}$ between both coals, and the catalytic effect of the iron on the nitrogen distribution was much larger for LY coal.

\section{2. 4. Nitrogen Functionality in Char}

As shown in Fig. 5, iron catalysts decreased char-N yields at $900^{\circ} \mathrm{C}$ irrespective of coal type, and the extent of the decrease was larger with LY coal. The effect of the iron on nitrogen functionality in LY char was thus examined by XPS. It has been accepted that XPS is the most successful technique to study the functionality of nitrogen in coal and char ${ }^{26)}$ 28). When the atomic ratios of N/C determined by both N 1s XPS measurements and elemental analysis were compared for several samples with and without the iron, there was the excellent surface:bulk correlation.

The proportion of nitrogen functional groups in LY char pyrolyzed at $900^{\circ} \mathrm{C}$ is shown in Table 4, where a least-square curve fitting method using Gaussian peak shapes is used for peak resolution, and pyridinic, pyrrolic, and quaternary nitrogen forms are resolved at 398.7, 400.3, and $401.4( \pm 0.1) \mathrm{eV}$, respectively ${ }^{29}$. Without the iron, pyrrolic nitrogen was the dominant species followed by pyridinic form, as reported in the previous studies ${ }^{27,28)}$. The presence of the catalyst decreased the proportion of pyrrolic and pyridinic forms, whereas it increased quaternary nitrogen.

When char samples were subjected to Ar ion sputtering with the rate of several $\mathrm{nm} / \mathrm{min}$, the proportion of quaternary nitrogen did not change for the original char, but on the contrary it decreased remarkably for the iron-bearing char (Table 4). Since it has been suggested that quaternary nitrogen species are pyridinic

Table 4 Change in Nitrogen Functionality in Char during Pyrolysis of LY Coal at $900^{\circ} \mathrm{C}$

\begin{tabular}{clccl}
\hline \multirow{2}{*}{$\begin{array}{c}\text { Iron loading } \\
{[\mathrm{wt} \%]}\end{array}$} & \multicolumn{2}{c}{ Functional groups [mol/\%] } & \multirow{2}{*}{$\begin{array}{c}\text { Pyrrolic/ } \\
\text { pyridinic }\end{array}$} \\
\cline { 2 - 4 } & Pyrrolic & Pyridinic & Quaternary & \\
\hline 0 & $59(47)^{\mathrm{a})}$ & $37(49)^{\mathrm{a})}$ & $4(4)^{\mathrm{a})}$ & $1.6(0.96)^{\mathrm{a})}$ \\
2.8 & $48(35)$ & $34(63)$ & $18(2)$ & $1.4(0.56)$ \\
\hline
\end{tabular}

a) After Ar sputtering. forms associated with hydroxyl oxygen ${ }^{27)}$, it is likely that the quaternary nitrogen observed in the presence of the iron before Ar sputtering is formed by interactions between pyridinic forms and surface hydroxyl groups on the iron catalyst. This is supported by the result that pyridinic nitrogen was the predominant species after Ar sputtering (Table 4).

Table 4 also shows that the ratio of pyrrolic to pyridinic nitrogen is smaller in the presence of the iron and this phenomenon is more remarkable by Ar sputtering. These observations suggest that the catalyst promotes preferential conversion of pyrrolic form to $\mathrm{N}_{2}$.

\section{2. 5. Catalyst State and Char Structure}

Table 5 summarizes the species identified by XRD before and after pyrolysis of iron-loaded coals ${ }^{13), 14)}$. No diffraction lines attributable to iron species were detectable on LY coal with 2.8 wt\% Fe. The Fe XPS spectra of this sample and bulk compounds of $\mathrm{FeOOH}$ and $\alpha-\mathrm{Fe}_{2} \mathrm{O}_{3}$ showed the peaks at 711.1, 711.0, and $710.6 \mathrm{eV}$, respectively, suggesting that the present catalyst exists in the form of $\mathrm{FeOOH}$. When the Mössbauer spectra were measured, however, the present iron had a doublet, which differed from the spectrum of bulk compound of $\mathrm{FeOOH}$. The Mössbauer parameters, such as isomer shift and quadrupole splitting, for the precipitated iron were in good agreement with those for fine particles of $\mathrm{FeOOH}$ dispersed on an Australian brown coal ${ }^{9), 17)}$. These observations indicate that the iron precipitated onto LY coal exists in highly dispersed form of $\mathrm{FeOOH}$.

When LY coal with the iron was pyrolyzed at $600^{\circ} \mathrm{C}$ and $750^{\circ} \mathrm{C}$ (Table 5), $\mathrm{FeOOH}$ was reduced to metallic iron $\left(\alpha\right.$-Fe), but some remained partly oxidized $\left(\mathrm{Fe}_{3} \mathrm{O}_{4}\right.$ and $\left.\mathrm{Fe}_{1-x} \mathrm{O}\right)$. On the other hand, the pyrolysis at $900^{\circ} \mathrm{C}$ led to complete reduction to $\alpha$-Fe irrespective of iron loading. Since large amounts of reducing gases such as $\mathrm{H}_{2}, \mathrm{CO}$, and hydrocarbons were evolved upon pyrolysis, $\mathrm{FeOOH}$ could readily be reduced by these gases, even when inert He was used as a fluidizing gas. Notably, the XRD signals of cementite $\left(\mathrm{Fe}_{3} \mathrm{C}\right)$ and graphitized carbon appeared after pyrolysis of LY coal with 0.7-6.8 wt\% Fe (Table 5), whereas LY char with-

Table 5 Species Identified by XRD and Particle Size of Iron Catalysts

\begin{tabular}{|c|c|c|c|c|}
\hline Coal & $\begin{array}{c}\text { Iron loading } \\
\text { [wt\%] }\end{array}$ & $\begin{array}{c}\text { Temperature } \\
{\left[{ }^{\circ} \mathrm{C}\right]}\end{array}$ & Species identified by $X^{2} D^{a)}$ & $\begin{array}{l}\text { Particle size }{ }^{\text {b) }} \\
\text { [nm] }\end{array}$ \\
\hline LY & 2.8 & $-^{c)}$ & not detectable & n.a.d) \\
\hline LY & 6.0 & $600^{e)}$ & $\mathrm{Fe}_{3} \mathrm{O}_{4}(\mathrm{w}), \alpha-\mathrm{Fe}(\mathrm{s})$ & n.a. \\
\hline LY & 6.8 & 750 & $\mathrm{Fe}_{1-x} \mathrm{O}(\mathrm{w}), \alpha-\mathrm{Fe}(\mathrm{s})$ & n.a. \\
\hline LY & 0.73 & 900 & $\mathrm{Fe}_{3} \mathrm{C}(\mathrm{w}), \alpha-\mathrm{Fe}(\mathrm{w}), \mathrm{G}^{\mathrm{f})}(\mathrm{s})$ & $20-30$ \\
\hline LY & 2.8 & 900 & $\mathrm{Fe}_{3} \mathrm{C}(\mathrm{m}), \alpha-\mathrm{Fe}(\mathrm{w}), \mathrm{G}^{\mathrm{f}}(\mathrm{s})$ & $30-50$ \\
\hline LY & 6.8 & 900 & $\mathrm{Fe}_{3} \mathrm{C}(\mathrm{m}), \alpha-\mathrm{Fe}(\mathrm{s}), \mathrm{G}^{\mathrm{f}}(\mathrm{s})$ & $40-60$ \\
\hline BA & 1.2 & 900 & $\mathrm{Fe}-\mathrm{C}^{\mathrm{g})}(\mathrm{w}), \alpha-\mathrm{Fe}(\mathrm{vw})$ & $70-100$ \\
\hline
\end{tabular}

a) XRD intensities designated as vw (very weak), w (weak), m (medium), and s (strong). b) Determined by TEM. c) Before pyrolysis.

d) Not analyzed. e) in $\mathrm{H}_{2}$. f) Graphitized carbon. g) Austenite. 


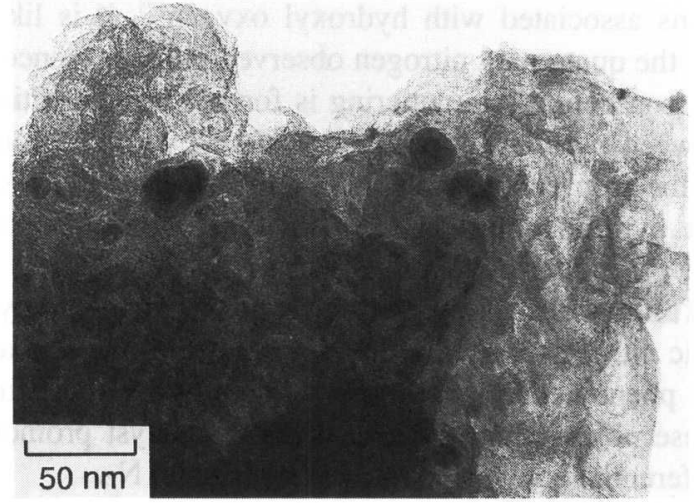

Fig. 6 Micrograph after Pyrolysis at $900^{\circ} \mathrm{C}$ of Loy Yang Coal with 0.7 wt $\% \mathrm{Fe}$

out the iron was amorphous. In the pyrolysis of BA coal with 1.2 wt $\% \mathrm{Fe}$ at $900^{\circ} \mathrm{C}$, however, $\mathrm{Fe}_{3} \mathrm{C}$ was not formed and the char remained amorphous (Table 5).

The TEM micrograph after pyrolysis of LY coal with $0.7 \mathrm{wt} \%$ at $900^{\circ} \mathrm{C}$ is presented in Fig. 6. The average size of iron particles was as small as $20-30 \mathrm{~nm}$. The XRD results (Table 5) suggest that both $\alpha$-Fe and $\mathrm{Fe}_{3} \mathrm{C}$ may be included in the observed particles. The TEM observations also revealed the presence of lamella structures attributed to graphitized carbon in the vicinity of catalyst particles. As summarized in Table 5 , the increase in iron loading on LY coal to $6.8 \mathrm{wt} \%$ slightly increased the average size, indicating a larger degree of catalyst agglomeration at a higher loading. The size of iron particles was dependent on coal type and larger for BA char in spite of a lower loading.

The formation of smaller nanoparticles on LY char is probably attributed to higher dispersion of the precipitated iron. The amount of $\mathrm{CO}_{2}$ evolved from LY coal increased linearly with increasing iron loading ${ }^{13)}$. Since $\mathrm{CO}_{2}$ is formed through decomposition reactions of $\mathrm{COOH}$ groups present in $\mathrm{coal}^{30)}$, the linear increase in $\mathrm{CO}_{2}$ yield with catalyst loading shows that most of $\mathrm{Fe}^{3+}$ ions interact strongly with free $\mathrm{COOH}$ groups unassociated with metal cations, which means the atomic dispersion of the iron. The iron would be less finely dispersed on BA coal with a smaller content of $\mathrm{COOH}$ groups.

\section{2. 6. Routes of Formation of $\mathrm{N}_{2}$ and Mechanism of Solid-phase Conversion to $\mathbf{N}_{\mathbf{2}}$ with Iron}

As can be expected in Fig. 5, the changes in the amounts of $\mathrm{N}_{2}$, volatile- $\mathrm{N}$ (comprising $\mathrm{HCN}, \mathrm{NH}_{3}$, and $\operatorname{tar}-\mathrm{N}$ ), and char- $\mathrm{N}$ by catalyst addition indicate that the iron added to LY coal always increases $\mathrm{N}_{2}$, whereas it decreases volatile- $\mathrm{N}$ and char- $\mathrm{N}$, and the increased amount of $\mathrm{N}_{2}$ is nearly equal to the sum of the decreased amounts of volatile-N and char-N. Similar trend was observed with BA coal. These observations point out that not only volatile- $\mathrm{N}$ but char- $\mathrm{N}$ is the source of $\mathrm{N}_{2}$.

In one route of formation, $\mathrm{N}_{2}$ originates from secondary decomposition reactions of volatile- $\mathrm{N}$. This route is well understandable, since it has been accepted that some catalysts added to coal promote the secondary decomposition of volatiles evolved upon pyrolysis. Iron-containing materials are catalytically active for $\mathrm{NH}_{3}$ decomposition ${ }^{31)}$, and fine particles of iron metal supported on carbon catalyze selective conversion of $\mathrm{N}$-containing heterocyclic compounds to $\mathrm{N}_{2}{ }^{32}$. Since catalyst dispersion plays a crucial role in such gas-solid reaction, $\mathrm{N}_{2}$ formation can occur to a larger extent with smaller catalyst particles on LY char (Fig. 5).

Another route of formation is via solid phase reactions, which extract $\mathrm{N}_{2}$ from char- $\mathrm{N}$ and/or precursors. In order to verify this point, nitrogen-enriched carbons derived from PAN were first mixed with fine particles of iron metal having the size of $20 \mathrm{~nm}$ and then heated in an inert atmosphere ${ }^{33)}$. In fact, the iron catalyzed conversion reactions of the nitrogen in the carbon to $\mathrm{N}_{2}$. As shown in Table 5, not only $\mathrm{Fe}_{3} \mathrm{C}$ but also graphitized carbon was formed on the chars from LY coal with iron catalysts. Since the metal-catalyzed graphitization of amorphous carbon such as LY char proceeds through a cycle mechanism involving carbon dissolution into metal particles and subsequent decomposition of metal carbides ${ }^{34)}$, the following reaction scheme can be suggested for the formation of $\mathrm{Fe}_{3} \mathrm{C}$ and graphitized carbon ${ }^{14)}$ :

$$
\begin{aligned}
& \alpha-\mathrm{Fe}+\text { amorphous carbon }(\text { char- } \mathrm{C}) \rightarrow \mathrm{Fe}_{3} \mathrm{C} \\
& \mathrm{Fe}_{3} \mathrm{C} \rightarrow \alpha \text { - } \mathrm{Fe}+\text { graphitized carbon }
\end{aligned}
$$

It is likely that the reaction between $\alpha$-Fe and char- $\mathrm{N}$ also takes place in this process ${ }^{14}$.

$$
\begin{aligned}
& \alpha-\mathrm{Fe}+\text { char- } \mathrm{N} \rightarrow \mathrm{Fe}_{x} \mathrm{~N}\left(\text { or } \mathrm{Fe}_{x} \mathrm{C}_{y} \mathrm{~N}\right) \\
& \mathrm{Fe}_{x} \mathrm{~N}\left(\text { or } \mathrm{Fe}_{x} \mathrm{C}_{y} \mathrm{~N}\right) \rightarrow \alpha-\mathrm{Fe}+\mathrm{N}_{2}
\end{aligned}
$$

Metallic iron first reacts with pyrrolic and pyridinic nitrogen forms in the char substrate to form interstitial iron nitrides, which are subsequently decomposed to $\alpha$ $\mathrm{Fe}$ and $\mathrm{N}_{2}$, because the nitrides are thermally unstable under the present conditions. As shown in Fig. 2, nanoparticles of metallic iron promoted formation of $\mathrm{N}_{2}$ from condensed heterocyclic ring structures, formed during carbonization of PAN.

Table 5 showed the formation of iron particles having smaller size on LY char than on BA char. Since a more finely dispersed metal has higher reactivity and larger mobility, the iron in LY char can more readily not only react with char- $\mathrm{N}$ but also migrate in the char matrix, and consequently solid-solid reactions can proceed at a higher rate to a larger extent, which leads to higher $\mathrm{N}_{2}$ yield and lower char- $\mathrm{N}$ yield for LY coal (Figs. 4 and 5). 


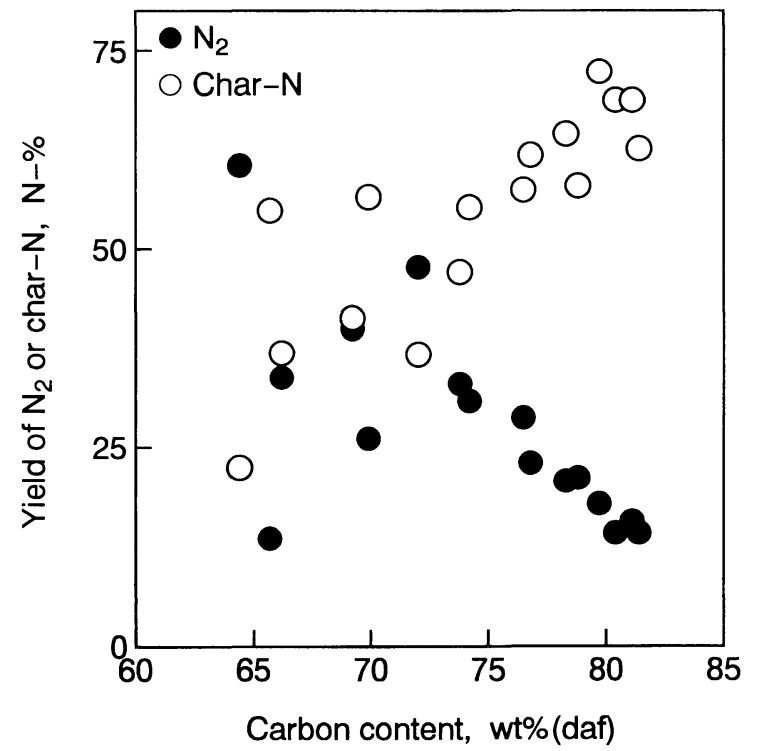

Fig. 7 Yields of $\mathrm{N}_{2}$ and Char-N as a Function of Carbon Content in Coal during Pyrolysis of Different Coals at $1000^{\circ} \mathrm{C}$

\section{3. Catalytic Role of Inherent Minerals in $\mathbf{N}_{2}$ Formation during Coal Pyrolysis}

\section{3. 1. Formation and Source of $\mathbf{N}_{2}$ from Different Coals}

Figure 7 shows yields of $\mathrm{N}_{2}$ and char- $\mathrm{N}$ at $1000^{\circ} \mathrm{C}$ for varying carbon content $(\% \mathrm{C})$ in coal ${ }^{16)}$. $\mathrm{N}_{2}$ yield depended strongly on coal type, in particular for lowrank coals with $\% \mathrm{C}$ of $\leq 72 \mathrm{wt} \%$. Surprisingly, a German RB coal exhibited the highest yield as large as $61 \%$, followed by a Chinese $\mathrm{ZN}$ coal which provided $\mathrm{N}_{2}$ yield of $48 \%$. Although many studies on nitrogen release during coal pyrolysis have been carried out ${ }^{6)-8)}$, most researchers have paid almost no attention to $\mathrm{N}_{2}$ formation, and such remarkable formation of $\mathrm{N}_{2}$ in the absence of catalyst is thus the first finding. As is seen in Fig. 7, RB coal showed the lowest yield of char-N, and it tended that char- $\mathrm{N}$ yield increased with increasing $\% \mathrm{C}$ in the range of $\geq 74 \mathrm{wt} \%$, in contrast with the decrease in $\mathrm{N}_{2}$ yield in this region.

The temperature dependence of distribution of nitrogen for ZN coal is illustrated in Fig. 8, where R and D denote the raw and demineralized coal, respectively ${ }^{35)}$. Nitrogen balance fell within the reasonable range of $97-$ $102 \%$. With the raw coal, at $600^{\circ} \mathrm{C}$, tar- $\mathrm{N}$ and $\mathrm{NH}_{3}$ were the main products, and only a slight amount of $\mathrm{N}_{2}$ was formed. On the other hand, $\mathrm{N}_{2}$ was the dominant species at $800^{\circ} \mathrm{C}$, where the release of volatile- $\mathrm{N}$ was almost complete. $\mathrm{N}_{2}$ yield increased linearly with increasing temperature, but contrarily char- $\mathrm{N}$ yield decreased with temperature.

In order to elucidate possible sources of $\mathrm{N}_{2}$, yield of volatile- $\mathrm{N}$ or char- $\mathrm{N}$ as function of yield of $\mathrm{N}_{2}$ is plotted for all of coal samples examined in Fig. 9, where

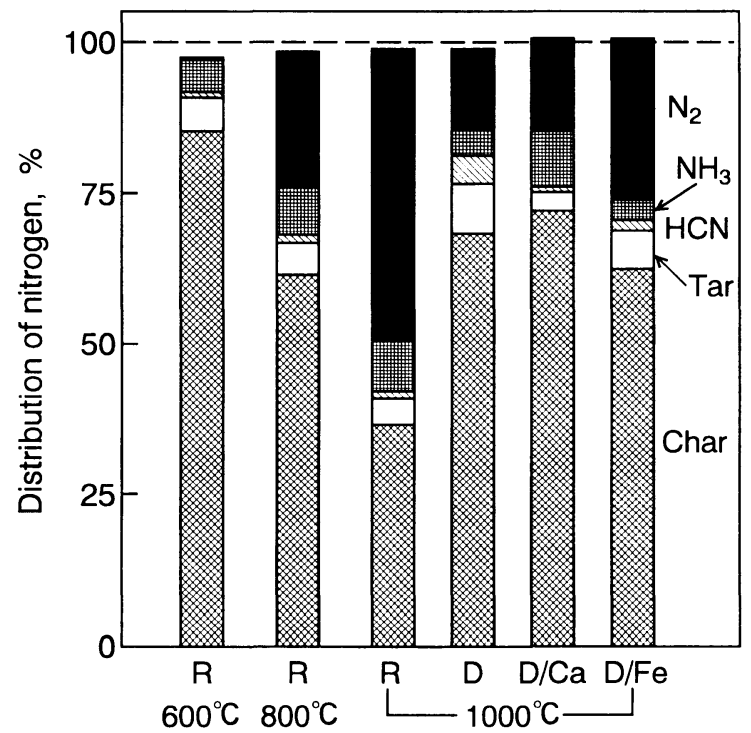

Fig. 8 Effects of Temperature, Demineralization of Coal, and Addition of Catalyst on Distribution of Nitrogen at $1000^{\circ} \mathrm{C}$ for Zalainuour Coal

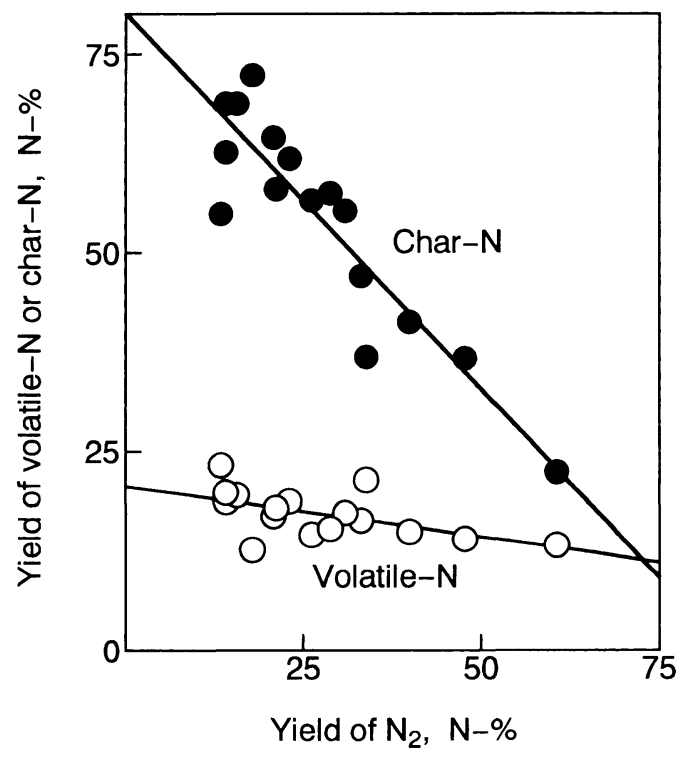

Fig. 9 Relationship between Yield of $\mathrm{N}_{2}$ and Yield of Volatile-N or Char-N during Pyrolysis of Different Coals at $1000^{\circ} \mathrm{C}$ (Reprinted with permission from reference No. 16, Copyright (1997) American Chemical Society)

volatile- $\mathrm{N}$ comprises $\mathrm{HCN}, \mathrm{NH}_{3}$, and tar- $\mathrm{N}^{16}$. Volatile- $\mathrm{N}$ decreased slightly as $\mathrm{N}_{2}$ increased, which shows that some of the $\mathrm{N}_{2}$ originates from volatile- $\mathrm{N}$, but its contribution to $\mathrm{N}_{2}$ formation is minor. On the other hand, char- $\mathrm{N}$ yield remarkably decreased almost linearly with increasing $\mathrm{N}_{2}$ yield. In other words, there was a strong, reverse correlation between char- $\mathrm{N}$ and $\mathrm{N}_{2}$. This observation indicates that char- $\mathrm{N}$ (and/or 
Table 6 Changes in Ash Content, Metal Composition, and Yields of $\mathrm{N}_{2}$ and Char- $\mathrm{N}$ by Demineralization

\begin{tabular}{|c|c|c|c|c|c|c|c|c|}
\hline \multirow{2}{*}{ Coal } & \multirow{2}{*}{$\begin{array}{c}\text { Ash } \\
{[w t \%]}\end{array}$} & \multicolumn{5}{|c|}{ Metal content in coal [wt $\%$ ] } & \multicolumn{2}{|c|}{ Yield $^{\text {a) }}[\mathrm{N}-\%]$} \\
\hline & & $\mathrm{Mg}$ & $\mathrm{Al}$ & $\mathrm{Si}$ & $\mathrm{Ca}$ & $\mathrm{Fe}$ & $\mathrm{N}_{2}$ & Char-N \\
\hline ZN-raw & 4.1 & 0.08 & 0.21 & 0.34 & 0.96 & 0.26 & 48 & 37 \\
\hline ZN-dem ${ }^{\text {b) }}$ & 0.8 & 0.03 & 0.12 & 0.27 & 0.11 & 0.10 & 13 & 68 \\
\hline RB-raw & 4.7 & 0.35 & 0.07 & 0.56 & 1.01 & 0.56 & 61 & 22 \\
\hline RB-dem ${ }^{\text {b) }}$ & 1.5 & 0.14 & 0.04 & 0.55 & 0.28 & 0.24 & 32 & 47 \\
\hline
\end{tabular}

a) Pyrolysis at $1000^{\circ} \mathrm{C}$. b) Demineralized coal.

precursors) is the major source of $\mathrm{N}_{2}$. This can be supported by the result that $\mathrm{N}_{2}$ formation takes place predominantly after almost complete release of volatile-N (Fig. 8).

\section{3. 2. Effects of Demineralization of Coal and Addition of Catalyst on $\mathbf{N}_{2}$ Formation}

It is well known that some minerals inherently present in coal, mainly metal cations as the ion-exchangeable forms in low-rank coals, can influence its pyrolytic reactions. This section thus clarifies the effect of demineralization on formation of $\mathrm{N}_{2}$ from $\mathrm{ZN}$ and $\mathrm{RB}$ coals which showed high $\mathrm{N}_{2}$ yields.

These coals were first demineralized with $5 \mathrm{~N} \mathrm{HCl}$ at $50^{\circ} \mathrm{C}$ and then pyrolyzed in the same manner as above. The results are summarized in Table 6 and Fig. $\mathbf{8}^{15), 16), 35)}$. As expected, the ash contents in $\mathrm{ZN}$ and RB coals were greatly decreased by demineralization. The composition of the main five elements present in these coals also changed considerably. Removal of $\mathrm{Ca}$, as the dominant species in both coals, was the highest, followed by Fe. As shown in Table 6 and Fig. $\mathbf{8}$, demineralization changed distribution of nitrogen drastically irrespective of type of coal; $\mathrm{N}_{2}$ increased, whereas char- $\mathrm{N}$ increased. Table 6 also indicates that the decreases in $\mathrm{N}_{2}$ yield by demineralization, $35 \%$ and $29 \%$ for $\mathrm{ZN}$ and $\mathrm{RB}$ coals, are roughly equal to the increases in char-N yield, $31 \%$ and $25 \%$ for the corresponding coals. These results agreed with the reverse correlation of char- $\mathrm{N}$ with $\mathrm{N}_{2}$ (Fig. 9). It is evident that some minerals in these coals control $\mathrm{N}_{2}$ formation upon pyrolysis.

Since Ca element was mainly removed by $\mathrm{HCl}$ washing (Table 6), it may have the catalytic effect on formation of $\mathrm{N}_{2}$ from $\mathrm{ZN}$ and RB coals. The demineralized $\mathrm{ZN}$ coal was thus exchanged with the Ca cations in a saturated solution of $\mathrm{Ca}(\mathrm{OH})_{2}{ }^{35)}$, and the resulting sample, denoted as D/Ca in Fig. 8, was subjected to pyrolysis runs. The calcium at a loading of $3 \mathrm{wt} \%$ had no significant effect on $\mathrm{N}_{2}$ yield (Fig. 8). In other words, it was almost inactive for $\mathrm{N}_{2}$ formation under the present conditions. When the nanophase iron oxide was added to the demineralized $\mathrm{ZN}$ coal, however, the iron at a low loading of $1 \mathrm{wt} \%$ promoted $\mathrm{N}_{2}$ formation and doubled $\mathrm{N}_{2}$ yield (Fig. 8), though it was less than the yield for the raw coal. The beneficial

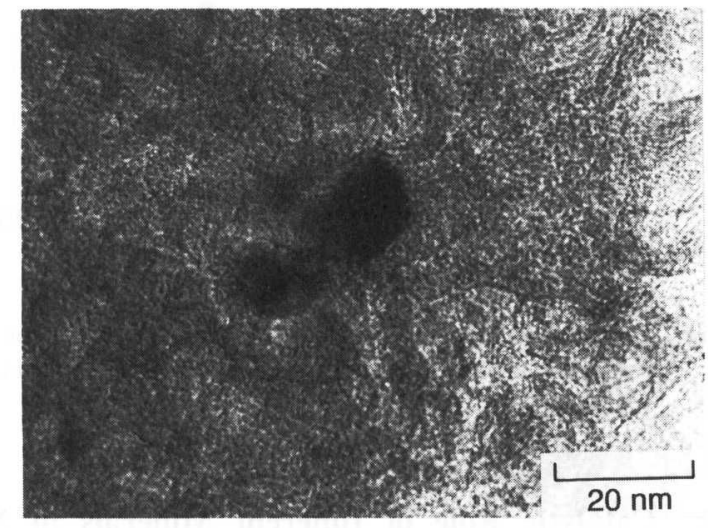

Fig. 10 Micrograph after Pyrolysis at $1000^{\circ} \mathrm{C}$ of Rhein Braun Coal

effect of the iron could readily be expected from the above-mentioned results. The nanophase iron catalyst added to the demineralized RB coal had almost the same effect on $\mathrm{N}_{2}$ formation as above. These observations strongly suggest that $\mathrm{Fe}$-containing minerals naturally present in $\mathrm{ZN}$ and $\mathrm{RB}$ coals account for the remarkable formation of $\mathrm{N}_{2}$.

The TEM-EDX analysis after pyrolysis of RB coal at $1000^{\circ} \mathrm{C}$ revealed that iron particles were finely dispersed in the char and the size was as small as 10-20 nm. A typical micrograph is shown in Fig. 10 $^{36}$. Lamella structures attributable to graphitized carbon also existed in the char matrix, as observed after pyrolysis of LY coal with precipitated iron (Fig. 6). When the RB demineralized coal with the nanophase iron was pyrolyzed at $1000^{\circ} \mathrm{C}$, however, graphitized carbon was not formed, and the size of iron particles was much larger. Thus, the iron derived from Fe-containing minerals provided more highly dispersed iron than the nanophase catalyst physically mixed with the demineralized coals, and in turn showed higher catalytic activity for $\mathrm{N}_{2}$ formation. It is known that the iron naturally present in low-rank coals exists in the ion-exchangeable forms, which initially provide essentially atomic dispersion $^{37)}$, as with the iron precipitated onto LY coal.

There is no doubt, therefore, that iron nanoparticles, which are formed from Fe-containing minerals present in $\mathrm{ZN}$ and $\mathrm{RB}$ coals, can promote $\mathrm{N}_{2}$ formation through 
the same routes as discussed with iron catalysts on LY coal. $\mathrm{N}_{2}$ formation after almost complete release of volatile-N (Fig. 8) and a strong, reverse correlation between $\mathrm{N}_{2}$ and char-N (Fig. 9) indicate that the mineral derived iron catalyzes predominantly solid phase reactions to extract $\mathrm{N}_{2}$ from char- $\mathrm{N}$ and/or precursors.

\section{Conclusions}

Nitrogen release from several coals with and without catalyst during pyrolysis under atmospheric pressure has been studied with a quartz reactor, and summary of conclusions follows:

1) $\mathrm{A} \mathrm{Cl}$-free iron precipitated onto an Australian brown or bituminous coal from $\mathrm{FeCl}_{3}$ solution promotes conversion of fuel- $\mathrm{N}$ to $\mathrm{N}_{2}$ at low loadings of $0.2-0.7$ wt\% Fe. The catalytic effect is much higher for the brown coal, and $\mathrm{N}_{2}$ yield at $900^{\circ} \mathrm{C}$ reaches $50 \%$, which is greater by 15 times that without the iron.

2) In contrast, the iron decreases yields of volatile- $N$ (comprising tar- $\mathrm{N}, \mathrm{HCN}$, and $\mathrm{NH}_{3}$ ) and char- $\mathrm{N}$. The analysis of nitrogen mass balance points out that $\mathrm{N}_{2}$ originates from solid phase reactions of char- $\mathrm{N}$ and/or precursors as well as from secondary decomposition reactions of volatile-N.

3) Not only $\alpha-\mathrm{Fe}$ and $\mathrm{Fe}_{3} \mathrm{C}$, but also graphitized carbon existed in the chars derived from iron-loaded brown coals, and the size of iron particles is smaller than that on the bituminous coal char. It is proposed in the route of formation of $\mathrm{N}_{2}$ from char- $\mathrm{N}$ that nanoparticles of metallic iron react with char- $\mathrm{N}$ to form interstitial iron nitrides, which subsequently decompose to $\mathrm{N}_{2}$.

4) Low-rank coals from China and Germany show exceptionally high $\mathrm{N}_{2}$ yields of $50-60 \%$ at $1000^{\circ} \mathrm{C}$, even without any catalysts. $\mathrm{N}_{2}$ starts to evolve after almost complete release of volatile- $\mathrm{N}$, and there is a strong, reverse correlation between $\mathrm{N}_{2}$ and char- $\mathrm{N}$. These observations show that char- $\mathrm{N}$ and/or precursors are the main source of $\mathrm{N}_{2}$.

5) Demineralization with $\mathrm{HCl}$ washing dramatically suppresses formation of $\mathrm{N}_{2}$ from these low-rank coals by removing mainly $\mathrm{Fe}$ - and $\mathrm{Ca}$-containing minerals. A nanophase iron catalyst added to the demineralized coals promotes $\mathrm{N}_{2}$ formation, but the addition of $\mathrm{Ca}(\mathrm{OH})_{2}$ has almost no effect on it. Upon pyrolysis, Fe-containing minerals in the ionexchangeable forms are transformed into finely dispersed iron, which catalyzes efficient conversion of char- $\mathrm{N}$ to $\mathrm{N}_{2}$ in solid phase.

6) Thus, iron nanoparticles, derived not only from externally added catalysts, but from inherently present minerals, play crucial roles in the selective conversion of fuel-bound nitrogen to $\mathrm{N}_{2}$. Since the presence of oxygen-containing functional groups is essentially needed for the formation of the iron, iron- catalyzed conversion reactions to $\mathrm{N}_{2}$ would proceed efficiently in the pyrolysis of low-rank coals.

\section{Acknowledgment}

The present work was supported by Grant-in-Aids for Developmental Scientific Research from the Ministry of Education, Science, Sports and Culture, Japan, and by the Proposal-Based New Industry Creative Type Technical R\&D Promotion Program from the New Energy and Industrial Technology Development Organization (NEDO), Japan. The author expresses his deepest gratitude to Dr. Kenji Asami, Dr. Takashi Watanabe, Mr. Hiroshi Mori, and Dr. Zhiheng $\mathrm{Wu}$ as co-workers, and gratefully acknowledges the assistance of Ms. Naomi Katahira, Ms. Ayumi Shoji, and Ms. Hazuki Satake in carrying out experiments. The author is also grateful to Prof. Akira Tomita of our Institute, Dr. Edward Furimsky of IMAF Group, Ottawa, Canada, and Dr. Marek A. Wójtowicz of Advanced Fuel Research, East Hartford, U.S.A., for their helpful discussions and suggestions.

\section{References}

1) Hjalmarsson, A.-K., "NO $x$ Control Technologies for Coal Combustion," IEACR/24, IEA Coal Research, London (1990), p. 162 .

2) Unsworth, J. F., Barratt, D. J., Roberts, P. T., "Coal Quality and Combustion," Coal Science and Technology, Vol. 19, Elsevier, Amsterdam (1991), p. 579-590.

3) Boardman, R., Smoot, L. D., "Fundamentals of Coal Combustion for Clean and Efficient Use," Coal Science and Technology, Vol. 20, ed. by Smoot, L. D., Elsevier, Amsterdam (1993), p. 433-509.

4) Wójtowicz, M. A., Pels, J. R., Moulijn, J. A., Fuel Process. Technol., 34, 1 (1993).

5) Takashita, M., Sloss, L. L., Smith, I. M., " $\mathrm{N}_{2} \mathrm{O}$ Emissions from Coal Use," IEAPER/06, IEA Coal Research, London (1993), p. $1-28$.

6) Davidson, R. M., "Nitrogen in Coal," IEAPER/08, IEA Coal Research, London (1994), p. 1-32.

7) Johnsson, J. E., Fuel, 73, 1398 (1994).

8) Leppälahti, J., Koljonen, T., Fuel Process. Technol., 43, 1 (1995).

9) Ohtsuka, Y., Asami, K., Yamada, T., Homma, T., Energy Fuels, 6, 678 (1992)

10) Asami, K., Ohtsuka, Y., Ind. Eng. Chem. Res., 32, 1631 (1993).

11) Zhao, J., Huggins, F. E., Feng, Z., Lu, F., Shah, N., Huffman, G. P., J. Catal., 143, 499 (1993).

12) Watanabe, T., Ohtsuka, Y., Nishiyama, Y., Carbon, 32, 329 (1994).

13) Ohtsuka, Y., Mori, H., Watanabe, T., Asami, K., Fuel, 73, 1093 (1994).

14) Mori, H., Asami, K., Ohtsuka, Y., Energy Fuels, 10, 1022 (1996).

15) Zhiheng, W., Ohtsuka, Y., Energy Fuels, 10, 1280 (1996).

16) Zhiheng, W., Ohtsuka, Y., Energy Fuels, 11, 477 (1997).

17) Asami, K., Sears, P., Furimsky, E., Ohtsuka, Y., Fuel Process. Technol., 47, 139 (1996).

18) Morita, K., Miyachi, H., Hiramatsu, T., Carbon, 19, 11 (1981).

19) Fitzer, E., Frohs, W., Meine, M., Carbon, 24, 387 (1986).

20) Watanabe, T., Ohtsuka, Y., unpublished data. 
21) Baumann, H., Möller, P., Erdöl Erdgas Kohle, 44, 29 (1991)

22) Bassilakis, R., Zhao, Y., Solomon, P. R., Serio, M. A., Energy Fuels, 7, 710 (1993).

23) Ohtsuka, Y., Furimsky, E., Energy Fuels, 9, 141 (1995).

24) Ohtsuka, Y., Mori, H., Nonaka, K., Watanabe, T., Asami, K., Energy Fuels, 7, 1095 (1993).

25) Ohtsuka, Y., Asami, K., Energy Fuels, 9, 1038 (1995).

26) Nelson, P. F., Buckley, A. N., Kelly, M. D., Twenty-Fourth Symposium (International) on Combustion, The Combustion Institute, Pittsburgh, PA, 1992, p. 1259.

27) Kelemen, S. R., Gorbaty, M. L., Kwiatek, P. J., Energy Fuels, 8, 896 (1994).

28) Wójtowicz, M. A., Pels, J. R., Moulijn, J. A., Fuel, 74, 507 (1995).
29) Watanabe, T., Mori, H., Asami, K., Ohtsuka, Y., unpublished data.

30) Schafer, H. N. S., Fuel, 58, 667 (1979).

31) Leppälahti, J., Simell, P., Kurkela, E., Fuel Process. Technol., 29, 43 (1991).

32) Ohtsuka, Y., Matsuyama, T., unpublished data.

33) Ohtsuka, Y., Watanabe, T., Asami, K., Proceedings, 7th International Conference on Coal Science, Alberta, Canada, Vol. 2, 1993, p. 11.

34) Oya, A., Marsh, H., J. Mater. Sci., 17, 309 (1982).

35) Zhiheng, W., Ohtsuka, Y., Energy Fuels, 11, 747 (1997).

36) Ohtsuka, Y., Zhiheng, W., unpublished data.

37) Schafer, H. N. S., Fuel, 56, 45 (1977).

要旨

\title{
鉄ナノ徽粒子によるフュエル窒秦の $\mathrm{N}_{2}$ への選択的転換
}

\author{
大塚 康夫 \\ 東北大学反応化学研究所有機資源・材料化学研究センター, 980-8577 仙台市青葉区片平
}

石炭中のフュエル窒素を燃焼前の熱分解過程で無害な $\mathrm{N}_{2}$ と して除去することを目的として, 石炭熱分解時の $\mathrm{N}_{2}$ 生成に及 ほす鉄触媒, 反応条件, 炭種, 鈗物質の影響を検討した。

塩化鉄水溶液を用いて塩素フリーの鉄触媒を豪州褐炭上に沈 殿担持したところ， $\mathrm{N}_{2}$ 収率（窒素基準）は熱分解温度の上昇 とともに増加し $900^{\circ} \mathrm{C}$ では $50 \%$ に達した。これは無触媒時の 15 倍に相当する。一方, $\mathrm{N}_{2}$ 以外の $\mathrm{HCN}, \mathrm{NH}_{3}$, タールやチャ 一に移行する窒素の量はいずれも減少した。このような著しい $\mathrm{N}_{2}$ の生成反応は $1 \mathrm{wt} \%$ 程度の鉄の存在下で進行し, $\mathrm{H}_{2}$ は全く 不要であることが明らかとなった。触媒の効果は歴青炭では小 さくなったが，これは触媒の分散性に起因した。褐炭チャー上 では, $20 \sim 30 \mathrm{~nm}$ の微粒子が存在し, 金属鉄以外に炭化鉄や結 晶性炭素が観測されたことから，金属鉄微粒子がチャー中のピ ロール環やピリジン環構造と反応して窒化鉄が生成しその分解
により $\mathrm{N}_{2}$ が発生する固相反応経路が, $\mathrm{N}_{2}$ 生成のメインルート であると結論した。

中国やドイツ産の低炭化度石炭の熱分解では, 無触媒下でも, $\mathrm{N}_{2}$ 収率は $1000^{\circ} \mathrm{C}$ で 50 60\% に昇った。揮発分窒素の脱離後 に $\mathrm{N}_{2}$ が発生し, $\mathrm{N}_{2}$ の増加はチャー中窒素を減少させるので, チャーが $\mathrm{N}_{2}$ の主なソースである。これらの石炭を塩酸で洗浄 すると, $\mathrm{Ca}$ や $\mathrm{Fe}$ を含む鉱物質が主に除去され， $\mathrm{N}_{2}$ 収率は著 しく低下した。しかし, 脱鉱物質炭にCaイオンを添加しても, $\mathrm{N}_{2}$ 収率は変わらなかった。熱分解チャー中には, $10 \sim 20 \mathrm{~nm}$ の鉄微粒子とともに結晶性炭素が存在することから, イオン交 換状態で存在する鉄含有鉱物質が熱分解時にナノ微粒子に転化 し，沈殿担持した鉄触媒と同様に固相脱 $\mathrm{N}_{2}$ 反応を促進すると 推論した。

\section{Keywords}

Brown coal, Fuel-bound nitrogen, Heterogeneous catalysis, Iron nanoparticle, Molecular nitrogen, Pyrolysis 